\title{
Liberalisation, health and the World Trade Organisation
}

The contemporary globalisation project of which Baum writes rests on the promise that economic growth benefits all. ${ }^{1}$ Originally enforced through Structural Adjustment Programs' trinity of privatisation, reduced public spending and increased trade liberalisation, it is the benefits of the latter that now dominate the "globalisation is good" argument. So dominant is this claim that it deserves closer scrutiny.

\section{Liberalisation. Growth and inequality}

To the extent liberalisation promotes economic growth for poorer nations, it may help to reduce absolute poverty and so improve health. But there is surprisingly little evidence that liberalisation, in itself, promotes growth. ${ }^{2}$ Moreover, absolute poverty is not the same as relative poverty or inequality. Studies by the World Bank claim that liberalisation is "income neutral," generating the same rate of growth for rich and poor alike. ${ }^{3}$ This as much as admits that inequalities will continue to grow, simply because the denominators of rich and poor are unequal to begin with. A recent study of 40 developing and least developed nations found that trade openness increased poverty and inequality. ${ }^{4}$ Similarly, a World Trade Organisation (WTO) report, extolling how liberalisation would lead to greater "income convergence" between trading partners, found this was so, but only in a downwards (income declining) direction. ${ }^{5}$ As income inequalities rise, so do health, education and gender inequalities, and social instability.

Part of the problem is that liberalisation is unequally practised. Wealthy nations remain protectionist in areas where it benefits their interests while demanding open markets where it harms only poorer nations. Nowhere is this more obvious than in agriculture and textiles, where many rich nations continue to increase domestic subsidies while removing import tariffs only gradually and reluctantly. Developing nations lose US $\$ 700$ billion a year by this double standard, 14 times more than they receive in aid. ${ }^{6}$ Mexico, where poverty rates and income inequalities have risen dramatically since signing of the North American Free Trade Agreement (NAFTA) ${ }^{7}$ provides one of many examples. Progressive land reforms last century led to subsistence and small market production plots big enough to feed a family and earn some capital, but inadequate against American "modern" corporate farming practices. ${ }^{8}$ Following NAFTA, the Mexican government ended its subsidies to corn growers, the market was flooded by cheaper US imports (where production remains heavily subsidised) and Mexican corn production decreased by half. ${ }^{8}$ Ejido (collective) landowners have since been given the right to own and sell their land. With depressed commodity prices and American competition, peasant landowners will begin selling their holdings. This raises a medium term prospect of increased agri-corporate land ownership and a long term probability of increasingly poor and, once more, landless peasants.

Some economists are now finding that economic growth, over the long term, may inevitably increase income inequalities. ${ }^{10}$ Such is the logic of market distribution. UNDP estimates of global income shares by top and bottom quintiles, cited by Baum, reveal an even more dramatic trajectory of this trend when one compares the 3:1 ratio in 1830 , to 1997 s ratio of $74: 1{ }^{11}$ Health improved dramatically over this period, and continues to improve as wealth rises but only to a point: about US $\$ 10000$ GDP per capita. Gains past this threshold are associated with income equity and access to public services, particularly for the poor. Even the World Bank now acknowledges the importance of pro-poor development policies, yet it is these very policies that are being eroded by liberalisation. In Kerala, India, an exemplar of the low wealth/high health/income equity model, a media developed Western consumerist culture, alongside tariff reductions, is rejecting locally produced goods for imported luxuries, weakening the local entrepreneurial base. In China, another former exemplar, it is producing a dramatic growth in income inequalities.

Even if globalisation's promise of economic growth for all was true or equitable, it ignores the ecological limits of such growth. By one estimate, if all countries "developed" to the same consumption patterns found in the US, our species would require four more planets to exploit. ${ }^{12}$ Assume wealthier nations dropped their agriculture subsidies and opened their borders to exports from poorer nations. These products would have to get there some way. That some way remains fossil fuel driven. Unsurprisingly, transport related greenhouse gas emissions in North America have risen since NAFTA $^{13}$ while, globally, the negative health and environmental impacts of associated climate change will be borne disproportionately by those least benefitting from its causes.

\section{The role of governments and the WTO}

Baum is correct in asserting that the only thing standing between an environmentally bleak and socially divided future are strong, socially democratic governments. Until the mid-1990s, rising market income inequalities in many OECD nations were offset by progressive tax and public transfer systems. ${ }^{11}$ As public spending and investment declines, income inequalities rise. This is a direction in which most countries are now headed, and to such an extent that post-tax and transfer income inequalities in several countries, notably the US, are now growing more rapidly than market income inequalities alone ${ }^{14}$; that is, many governments are actively participating in globalisation's upwards redistribution of wealth and power. But there is little doubt the WTO, and its growing number of trade, investment and "trade related" agreements, further circumscribes the abilities of governments to pursue health and social development goals via economic policy variables. ${ }^{15}$

The "precautionary principle," so important in domestic and international environmental regulation, has been undermined by WTO tribunal decisions. The threat of sanctions under the TRIPS (Trade-Related Aspects of Intellectual Property Rights) Agreement alone caused Guatemala to rescind legislation based on the WHO/ UNICEF infant formula marketing code. (Gerber Foods claimed removing the picture of a "pudgy baby" from its products, as required by the code, was an expropriation of its trademark.) Both the EU and the US have threatened to use the WTO TBT (Technical Barriers to Trade) Agreement to prevent Japan from implementing legislation on automobile emissions as part of its Kyoto commitments. They argue the legislation would discriminate in favour of Japan's domestic car industry over their own more polluting imported cars. Current negotiations around GATS (General Agreement on Trade in Services) could further open public health, education and social services to global market competition and privatisation. This is at a time when these services are already under 
strain, as liberalised capital creates downward tax competition among countries leading to declines in tax revenues in rich and poor countries alike. ${ }^{16}$

WTO decisions to date have not favoured the pro-poor development policy free marketers now claim should smooth over globalisation's rough edges. In one case, the WTO prohibited preferential treatment by the EU for banana imports from its foreign colonies in the Caribbean, where production is small and farmer owned. This preference did not make economic sense, but it did make development sense. Without it, the economies of small island nations in the Caribbean will collapse. What was once a normative decision to aid poorer countries in need has become a market decision based solely on economic criteria. The WTO similarly ruled against the use of import protections by developing nations for purposes of improving poor living standards. "Development [or pro-poor] policy," the ruling concluded, is not the same as "macro-economic policy." Where there is a WTO dispute, the latter shall prevail. ${ }^{17}$

\section{To oppose or co-opt?}

WTO officials point out that its mandate is not to improve health, create justice or preserve the environment. It is to create rules allowing capital, already largely free of national boundaries, to become even freer, regardless of where it comes from or where it makes or ships its products. That those who benefit most from such rules are the already rich is a coincidence of history. That such rules means undoing the regulatory powers of national governments is a side effect many governments themselves appear to accept (though some critics argue often naively). After all, governments cite WTO environment and social safeguard clauses (usually unsuccessfully) when it protects their domestic economic interests, while challenging these same clauses (usually successfully) when it does not.

The WTO is less transparent and democratic than it needs to be. The WTO places the goal of liberalisation ahead of any of its human consequences. Enforceable WTO agreements conflict with many unenforceable UN social, environmental and health declarations. For these reasons many protest groups argue for its abolition, alongside that of the World Bank and IMF. But there are good reasons why we need to reform, rather than raze, the WTO. Capitalism needs rules if it is to be socially just and ecologically viable. Socially democratic states, those with strong civil societies and organised labour, learned last century how to create those rules. The WTO presents a platform upon which such rules might be inscribed globally. Even WTO officials are calling for creation of a parallel World Environmental Organisation with similar enforcement powers. There are calls for elected representation to the WTO. Many nations now are urging curbs over the speculative risks of liberalised capital through imposition of a "financial transaction" or "Tobin" tax.
Some WTO observers claim optimistically that the next great task economic globalisation is already encountering is the integration of human development goals within trade and investment agreements.

Without the rules-based platform of the WTO, or parallel bodies governing regional free trade agreements, economic globalisation will remain the prerogative of elites within the US, Japan and the EU. The task, as Baum challenges us, is to co-opt the rules for the common good. There are three simple contributions health researchers and professionals can make:

1 Engage in commentaries and debates within their own spheres of influence. Health is a more powerful and neutral metaphor by which progressive legislation might be levered than is social justice.

2 Extend these commentaries to the public media, and to national politicians and trade bodies such as the WTO.

3 Study (or synthesise existing research on) the various pathways by which changes brought on by economic globalisation might determine health, especially in future generations. Harness the intellect and rigour of research to the engine of civil society mobilisation.

RONALD LABONTE

University of Saskatchewan and University of Regina, Canada and Saskatchewan Population Health and Evaluation Research Unit

1 Baum F. Health, equity, justice and globalisation: some lessons from the People's Health Assembly. I Epidemiol Community Health 2001;55:613-6.

2 Rodriguez,F Rodrik D. Trade policy and economic growth: a skeptic's guide to the cross-national evidence. Geneva: University of Maryland and Harvard
the the cross-national

3 Dollar D, Kraay A. Growth is good for the poor. Washington: World Bank, 2000. (www.worldbank.org/research)

4 Rao JM. Openness, poverty and inequality in background papers human development. Report 1999, vol 1. New York: UNDP, 1999.

5 World Trade Organization. Trade, income disparity and poverty. Special Study 5. Boston: WTO, 1999

6 Watkins $\mathrm{K}$. The world must rein in the wreckers who trade in misery. The Guardian January 18-24 2001;23.

7 Wallach L. Impact of NAFTA on the US Economy: Testimony before the International Trade Commission. May 15, 1997; http://www.islandnet.com/ $\sim$ ncfs/maisite/failure.htm

8 Mexico Survey. The Economist October 28, 2000

9 Wallach L, Sforza M. Whose trade organisation? Washington: Public Citizen, 1999.

10 Laroche M, Mattina T. Session no 6. Public policy, inequality and growth: Can fiscal policy lessen earnings inequality? Ottawa: IRPP-CSLS Conference: Linkages Between Economic Growth and Inequality, 2001.

11 UNDP. Human Development Report 1999. New York: Oxford University Press, 1999.

12 See Footprints of the Planet Report, http://www.iclei.org/iclei/ecofoot.htm

13 North American Commission on Environmental Cooperation. Assessing environmental effects of the North American Free Trade Agreement (NAFTA): an analytic framework (phase II) and issue studies. Montreal: NACEC: Environment and Trade Series 6, 1999.

14 Mintz J, Aba S. Session no 1. Trends in inequality and growth in Canada and the United States. Sharing the wealth from growth: comparing the Canadian and US experiences. Ottawa: IRPP-CSLS Conference: Linkages Between Economic Growth and Inequality. 2001.

15 Reinicke W. Global public policy: governing without government? Washington: Brookings Institute, 1998 .

16 Rodas-Martini P. Income inequality between and within countries: main issues in the literature in background papers Human Development Report 1999. Vol 1. New York: UNDP, 1999.

17 Raghaven C. WTO members awaiting new draft text for Seattle. Third World Network 10/17/99; http://www.twnside.org.sg/souths/twn/title/new draft, 1999 